\title{
THE APPRENTICESHIP SYSTEM OF THE GENERAL ELECTRIC COMPANY AT WEST LYNN, MASSACHUSETTS
}

\author{
By Magnus W. Alexander.
}

The recent period of unprecedented industrial prosperity has revealed in a striking manner to the American people that the supply of skilled workmen in this country is utterly inadequate. Even during the business depression that set in over a year ago, the demand for skilled and intelligent mechanics and foremen has in most instances been greater than the supply. Uniess we eliminate this great weakness in our industrial system, we may well look with apprehension to the time when the wheels of industrial activity will again turn at a lively speed. Thoughtful and far-sighted men should, therefore, give close and careful consideration to this matter in order to avoid a future check on the industrial development of the country.

In the main, there are three methods by which the youth of this country can be trained for a life of industrial efficiency,- the apprenticeship system, the private trade school, and the public school. Whichever method of industrial education is selected in any particular case to meet the needs and conditions of a community, it can be effective only if it is based on the broad principle of correlating the training of the hand with the development of the mind in the effort to obtain skill and intelligence. Skill cannot demonstrate its full potential value and reap its highest reward unless it is supplemented by an industrial intelligence which animates the otherwise routine activities of daily life, and makes men conscious of the why as well as the how of all work. The joy that one then derives from his work will enhance the value of his task and give it individual significance.

The apprenticeship system of the General Electric Company at West Lynn, Mass., is perhaps the best exemplification of the efficacy of this principle, and inasmuch as similar systems have since been established by other manufacturing organizations, and the same idea has been adopted by trade schools founded in recent years, a brief 
description of the origin, the progress and the effect of the Lynn system seems to be justified.

The General Electric apprenticeship system was founded seven years ago, when the Lynn works employed about 5,000 workers; and it has been developed to its present state during a time when the number of employees in the machine shops, pattern shop and the foundries of the plant has more than doubled. Its organization was based on a study of the then known apprenticeship system, an analysis of its inherent weaknesses, and an application of the proper remedies.

Before this time apprentices were assigned to shop departments whose foremen, being business men as well as mechanics in the fulfilment of their duties, could take only a general interest in the boys, and had to rely mainly on assistants for the training of the apprentices. It is obvious that the apprentices were, therefore, not placed under the most advantageous instruction. Inasmuch as the shop foreman lacked the personal interest in the boy that the journeyman master of thirty years ago had shown, and was actuated primarily by a desire for economic production, he was loath to put a new apprentice on a machine for fear that he might injure it on account of insufficient personal attention. He was apt to keep the boy unduly long on an operation which he had learned, in order to get the greatest commercial advantage from him. The sameness of operations in one department helped to militate still further against the apprentice of that department, who found himself at a disadvantage when contrasted with one who had had an opportunity of a greater variety of instructive work in some other department of the factory. The desire of the apprentice to learn came in conflict with the purpose of the foreman to secure economy by cheapness of production, and while the fittest of the boys survived what proved to be a hard struggle for success, many fell by the wayside who, under more favorable conditions, might have developed into efficient and skilled mechanics.

The employment of a supervisor of apprentices by some manufacturers was a step in the right direction, and eliminated some of the existing defects in the training of boys. Representing the employer as well as the apprentices, the supervisor served both in looking after the general welfare of the boys, advancing them from one kind of work to another. To the extent to which he possessed 
breadth of view and ability to secure the co-operation of the foremen, he fulfilled his dual task to the advantage of the boys and the employer. There still remained a deficiency in the system, in that those in direct charge of the training of the boys did not usually measure up to the best teaching ability. The significance of this weakness is most important in that a solid or faulty foundation of training, after all, determines the strength or weakness of the whole structure of future achievement.

In order to get the best results from the apprenticeship system the General Electric Company at West Lynn, Mass., organized a special department-training rooms-devoted entirely to the preliminary practical training of the apprentices. It appointed a superintendent of apprentices who was especially qualified for the difficult task of teaching, and placed him in direct charge of the training rooms. Furthermore, it made an arrangement whereby such instructive commercial work could be transferred from the factory into the training rooms from time to time as the development of the apprentices might require. An equal and fair opportunity to learn a trade was, therefore, offered to all apprentices. Finally, the General Electric Company established classrooms in the factory in which the boys might receive mental training in the related sciences, and instruction in mechanical drawing, to the end that theory and practice might be correlated as far as possible. It is the aim of the company to develop skilled mechanics in the trades of machinist, toolmaker, patternmaker, iron, steel and brass molder, as well as to create a body of efficient and well-dispositioned journeymen upon whom the company may draw from time to time for industrial foremen and their assistants in the different departments of the factory, for tool designers, factory engineers, and other leading men in the organization. The training which a boy receives at Lynn is so broad, however, that the graduate apprentice is prepared to fill a position as skilled journeyman or as industrial foreman in any mechanical establishment.

By the terms of the apprentice agreement, boys of from fifteen to eighteen years of age, who have had at least a grammar school education or its equivalent and are physically sound, are eligible to the courses, which for machinist, toolmaker and patternmaker apprentices last four years, and for molder apprentices three years. Apprentices with an advanced education, however, are given an 
adequate allowance of time. All accepted applicants must serve a trial period of two months, and only those who during this period give proof of native ability for the chosen trade, and show a mental and moral make-up that gives hope of developing intelligent and welldispositioned journeymen, are permitted to sign the regular agreement. The latter is considered as an agreement of honor rather than one of legal force. The main motive of the whole training of the apprentices is to stimulate their ambition and arouse their zeal to develop themselves in order that they may advance from one task to another as rapidly as possible on the basis of acquired skill and efficiency.

Most of the applicants for apprenticeship reside, of course, in Lynn and vicinity, although many come from other parts of Massachusetts, from other New England states, and in fact from more distant parts of the country. In order to allow ambitious boys, not residing within easy reach of the factory and having no financial support from home, to take advantage of the opportunity offered at Lynn, the wages have been arranged for all apprentices so as to make the boys self-supporting even during the trial period. On the other hand, the company selects its material with great care and expects a fair return in work for the wages paid. In round figures, apprentices receive $\$ 5.00$ per week for the first year, inclusive of the trial period; $\$ 6.50$ per week for the second year; $\$ 7.75$ per week for the third year, and $\$ 9.00$ per week for the last year. Molder apprentices receive the wages of the last three years.

At the satisfactory termination of the course a "Certificate of Apprenticeship" and a cash bonus of $\$$ Ioo are awarded to the graduates, who are encouraged to remain with the company at such journeymen's compensation as they are able to earn. Usually from $\$ 2.50$ to $\$ 3.00$ per day is offered to the graduates, some of whom have been placed in positions of assistant foremen at adequate remuneration almost immediately after graduation from the apprenticeship courses. Some graduated apprentices, on the other hand, prefer to go to other factories, evidently desiring to broaden their experience and to see something of the world, as they express it. No attempt is made to dissuade them from carrying out their plans, but experience has shown that most of them return after a while to their alma mater, where they have made their friends. This feeling of loyalty is a gratifying assurance of the future personnel of the foremen and 
assistant foremen of the company, who will probably be drawn to a large extent from among the graduated apprentices. An apprentice alumni association fosters also this feeling of loyalty and comradeship.

Reference has already been made to the training room feature of the General Electric apprentice system as a means of initiating boys into a trade under most expert instruction and the most favorable conditions. The company maintains training rooms for machinist and toolmaker apprentices, and a separate room for the training of future patternmakers. No such provision has as yet been made for boys learning the molder's trade, but there is no good reason why this should not be done in the near future.

Beginning in a small way, with a floor space of about $75^{\circ}$ square feet and half a dozen old machine tools, the machinist training room has grown in size and equipment until to-day it covers an area of more than Io,000 square feet, with over Ioo representative machine tools. Similarly, the training room for patternmakers occupies a floor space of about 2,00o square feet, with a complete patternmakers' tool equipment for thirty-five or forty apprentices. It will be sufficient to describe here more in detail the methods of instruction in the machinist training room as illustrating the peculiar features of the Lynn system.

The present tool equipment in the machinist training room consists of twenty drill presses of various sizes, forty-four speed and engine lathes, some belt driven and some provided with individual motor drive; a pulley lathe, two turret lathes, two twenty-four-inch planers, one belt driven and one motor driven; nine shapers, one vertical boring mill, four plain and two universal horizontal milling machines, one vertical milling machine, one slotting machine, one spliner, two universal grinders, one surface grinder and three wet grinders, four tool grinders, one motor driven hack-saw and one cutting-off saw, two arbor presses, two bench watchmakers' lathes, besides a number of small electric bench drills, buffing and polishing motors, and forty vises. There is also a small blacksmith equipment and a stock of necessary small tools, such as drills, taps, reamers, chucks and arbors.

Many of the machines are of the latest and most approved type. Some are, however, second-hand tools which had been discarded by the shop foremen and relegated to the scrap heap. The use of old 
machines serves a two-fold purpose-the economic and the educational. It prevents the abuse and injury of high-priced modern tools by inexperienced boys, while at the same time it affords an opportunity for repairing machine tools, an excellent training for future mechanics in that it develops thoughtfulness, self-reliance and the ability to do things. In this way some of the old machines have been repaired again and again, being just as serviceable now as some of the high-priced modern tools.

Every boy who is admitted to the trial period starts his career in the training room, where he is under the direct supervision of the superintendent of apprentices, who is thus afforded an opportunity to study carefully the boy's mental capacity, his native ability for the chosen trade, and his general character. From the very outset the apprentice is required to do commercial work, even though this may be his first experience with machine tools. The training of the boy on commercial work is of great psychological importance, in that it takes him out of the sphere of laboratory work into that of industrial life. It clinches the boy's interest inasmuch as it makes him realize that the product of his work is to be a part of some useful machine rather than a plaything or an object of exhibition in some showcase. Commercial work teaches the boy the value of time and money and stimulates him by making him feel his place in real industrial life. Ample opportunity is given here to those who possess inventive ability, and each apprentice is taught individually and advanced in his work in accordance with his capacity. No schedule of time on the different machines is laid out, therefore; the apprentice is required to stay on one machine and one operation until he has proved his ability to perform this specific work with accuracy and a fair degree of speed. It may take some apprentices a year and a half and others almost double that time to pass through the training room. In due time the apprentices are transferred into the factory and assigned to various departments for the remainder of their apprenticeship. Thus they round out their knowledge and skill on a variety of work such as the factory offers.

Some may now begin to specialize on die- and tool-making, on large or small machine work, or on such other tasks for which they seem to be best fitted. These apprentices are under the discipline of the shop foreman and subject to the rules of the department, yet they still belong to the superintendent of apprentices and look to 
him for transfer to the various classes of work and for general guidance. They are even subject to temporary return to the training room when, in the opinion of the superintendent, they require closer attention because of their failure to keep up with speed and accuracy standards or to conduct themselves properly.

Inasmuch as most of the apprentices, in taking their positions later on in the factory organization, will be called upon to instruct those under them, an early effort is made in the training room to develop in the apprentices the ability to impart knowledge to others, to handle men and work. A method has, therefore, been adopted under which the apprentices are given frequent opportunities to act as temporary instructors. Accordingly, each apprentice, at various times during his stay in the training room, must help to instruct a less-advanced apprentice in the operation which he himself has already mastered. The general instructor, of course, starts off the team of boy teacher and boy pupil, but after he has done this he leaves the instructing and supervising to the boy teacher, returning from time to time, to make sure that the team is proceeding in the right direction.

It is obvious that the young master will put forth his best effort to impress the boy pupil with his own knowledge, and inasmuch as he is anxious to advance himself to some more difficult work, which he cannot do until the general instructor relieves him from the teaching work, he will take pains to put the boy pupil on his own feet. The latter, on the other hand, is anxious to stand on his own feet, and in turn to become a boy teacher; he is therefore eager to learn. Sometimes an apprentice acts as boy teacher to one who has already served a longer time in the training room than his instructor pro tem. This simply bears out the claim that all instruction in the training room is adapted as far as possible to the individual capacity of the apprentice, so that the capable one is not held back on account of other apprentices of lesser ability.

Under the boy-teacher and boy-pupil system only three journeymen instructors are required in the training room for about roo apprentices. The instructors are responsible for the teaching of the boys as well as for the production and the general business of the department. Even should the number of apprentices in the training room grow to $\mathrm{I} 25$, no addition to the instructing force would probably be made, but the present instructors would be assisted to a still 
larger degree by apprentices who are temporarily placed in charge of classes of work and groups of boys. For instance, at present an apprentice is responsible for the production of clutch pulleys in the training room. It is his duty to see that the boys engaged on this particular class of work attend properly to their duties and that the required number of clutch pulleys is turned out, tested, and put in shipping boxes every week. It is obvious that one or two months of such work tends to develop executive ability in those in whom this important quality lies dormant. The results obtained by apprentices in the training room are surprising even to those who watch the progress of work closely. It bears evidence that the possibilities of apprentices under proper guidance and instruction are remarkable if their ambition and interest in the work are aroused. This good and intelligent work, however, could not be accomplished if the classroom instruction, which is correlated with the practical training, did not make the apprentices mentally alert and place them in a position to read working drawings without difficulty, to compute every-day arithmetical factory problems and, in general, to understand the reason for every stroke of work which they perform.

The significant feature of the classroom instruction at Lynn lies in the fact that it is given to the boys during regular working time, rather than in the evening when, after a long day's hard work, the apprentices are usually neither mentally nor physically able to draw the greatest benefit from the instruction.

Every indentured apprentice receives instruction in the classroom for two hours four times a week, no school being held during part of July and August, so that the teachers and pupils may take their vacation at that time. Realizing that inasmuch as many boys have left school but recently in order to earn money, and on account of lack of appreciation of the value of education, the General Electric Company decided to pay apprentices the same wages during school hours that they would receive while working at the bench or machine. In this way, even those boys in whom the commercial spirit predominates and who therefore might not be willing to make an immediate financial sacrifice for the sake of possible greater returns later on, become anxious to secure an education. The improved character of the work of the apprentices in the training room and factory is the company's compensation for this expenditure. 
In addition, it helps to create journeymen with a training that will enable them to grow into positions of responsibility.

The school program embraces instruction in mathematics, physics, technology and mechanical drawing. The teachers, who have been selected from the staff of the company's engineers, draftsmen and foremen, aim to awaken and exercise the boys' reasoning faculties, and develop their ability to think for themselves, rather than provide them with specific knowledge.

In order to achieve this result and to give to all instruction a concrete value, thereby clinching the boys' interest in the work, the teachers confine themselves as far as possible to the explanation of principles through practical problems and to this end select problems from among the occurrences of daily factory life. This method has the added advantage of initiating the apprentices into the technicalities of the business by acquainting them with the apparatus manufactured and the different materials used in the shop, and familiarizing them with the very problems whose solution will be expected of them later on as journeymen, foremen, and engineers. To ascertain the weight of material required for the production of three electric motor shafts in accordance with a given drawing, and to estimate the labor cost on the basis of estimated time for machining, all of which merely requires the reasoning out of mathematical processes already learned in school, are of infinitely greater value to the apprentice than the computation of the cubical contents of a cylinder of given dimensions, which calls for the same mathematical processes but is dependent for its solution chiefly on the memory.

Similar value is gained from instruction in physics, if, for instance, the law of levers is deduced by the boys themselves from a series of experiments with varying weights and positions of the fulcrum carried on until they perceive the proper relation between weights and power arm and weight arm. Through practice to theory is the guiding principle in the educational work. Great emphasis of course is laid on the instruction in mechanical drawing, which aims to enable the apprentices to read drawings quickly and intelligently, and for that reason presupposes the ability to make drawings. This branch, however, is taught not so much for the purpose of developing mechanical draftsmen as to serve as a means of teaching the designing of tools and jigs and fixtures needed for manufacture 
on a large scale. A good tool maker is more valuable if he has the ability to design tools, and a good tool designer ought also to be a good tool maker. The combination of botl qualifications is a valuab!e asset to any mechanic.

Under the guise of teclinology, an attempt is made to develop in the apprentices the power of concise and clear oral and written expression, and inasmuch as materials and their characteristics, machines and machine elements and their functions are taken as the text of the instruction, the apprentices acquire a technical as well as a general knowledge. One of the most interesting and instructive phases of this part of the school work is the "practical talk" which the superintendent of apprentices gives once every week in the classrooms. If he sees a wrongly-sharpened tool somewhere in the factory, or notices the abuse of any machine, he is sure to bring this tool into the classroom or to relate the circumstances under which the machine has been misused, in order that the apprentices may avoid similar errors in their own work. "Practical talks" of this kind are bound to be of the greatest value to the apprentices, and therefore to the company when journeymen thus trained become part of the factory organization.

Groups of approximately fifteen boys form a class, some receiving instruction from 7 a. m. to 9 a. m., others from io a. $\mathrm{m}$. to 12 m., or during the first or last part of the afternoon. Three classroom instructors, therefore, may easily take care of approximately two hundred apprentices. There are nearly two hundred and fifty working at Lynn, including those who are serving their trial period, and are, therefore, not yet entitled to the classroom instruction. Seventy-six apprentices have so far graduated from the course and over fifty are at present in the employ of the company, some of whom are filling positions as assistant foremen and inspectors, a few having developed into very good tool designers. The apprenticeship system of the General Electric Company at Lynn proves that a broadly-conceived plan efficiently executed will work out to the advantage of all concerned. 